\title{
A Problem in Plato's Hagiography of Socrates
}

\author{
By Nicholas D. Smith*
}

\begin{abstract}
The problem for Plato's hagiography of Socrates can be stated as a trilemma: 1) Socrates is an exemplar of virtue; 2) Virtue is a kind of knowledge; and 3) Socrates lacks the knowledge in which virtue consists. The problem is that if we accept (2) and (3), it seems we must conclude that Socrates cannot be virtuous, which plainly conflicts with (1). If we accept (1) and (2), it seems we are forced to conclude that Socrates cannot be telling the truth when he disclaims having the knowledge of virtue (3). If we accept (1) and (3), it seems we cannot accept Socratic virtue intellectualism (2). This, then, appears to be an inconsistency in Plato's depiction of Socrates in the so-called "early" or "Socratic" dialogues. In this paper, I seek to show that we can actually accept each of the above claims. But in order to do so, we must recognize something about each one of the claims that has not received adequate attention in the scholarly literature. Once we attend to what has gone mostly unattended, however, the three claims can be seen as fully consistent.
\end{abstract}

\section{The Problem Stated}

Few would doubt that Plato intends to portray Socrates as an exemplar of virtue. In Plato's Apology, Socrates cites the authority of Delphi in support of his claim to be the wisest of men (23b2), if only because he is so well aware of his own ignorance. In Plato's other dialogues, as well, Socrates seems clearly to be identified as superior with respect to whatever positive trait or virtue is under discussion. In short, Plato seems to miss no opportunities to praise Socrates as a man who is superior to others. Here is how Plato has Alcibiades put it in the Symposium:

You could say many other marvelous things in praise of Socrates. Perhaps he shares some of his specific accomplishments with others. But, as a whole, he is unique; he is like no one else in the past and no one in the present - this is by far the most amazing thing about him. (Symposium 221c2-6) ${ }^{1}$

Plato's Socrates is also aware that "it is generally believed, whether it be true or false, that in certain respects Socrates is superior to the majority of men" (Apology 34e5-35a1). But as plausible as Plato makes such a view about Socrates, he also seems to create problems for that view in others positions he gives to Socrates. One of these is what has come to be known as Socratic

\footnotetext{
* James F. Miller Professor of Humanities, Department of Philosophy, Lewis \& Clark College, USA.

1. Unless otherwise noted, all translations provided herein are those given in Cooper [John M. Cooper, ed. Plato: Complete Works (Indianapolis: Hackett Publishing Company, 1997)].
} 
"virtue intellectualism" - the view that virtue is a kind of knowledge. The other is that Plato has Socrates persistently disclaim having the knowledge in which virtue consists. The problem for Plato's hagiography of Socrates, then, can be stated as a trilemma:

1. Socrates is an exemplar of virtue.

2. Virtue is a kind of knowledge.

3. Socrates lacks the knowledge in which virtue consists.

The problem is that if we accept (2) and (3), it seems we must conclude that Socrates cannot be virtuous, which plainly conflicts with (1). If we accept (1) and (2), it seems we are forced to conclude that Socrates cannot be telling the truth when he disclaims having the knowledge of virtue (3). ${ }^{2}$ If we accept (1) and (3), it seems we cannot accept Socratic virtue intellectualism (2).

The problem thus presented is not a new one to Socratic scholarship. In fact, we find it vividly expressed in Gregory Vlastos's earliest essay on Socrates: ${ }^{3}$

What would you expect of such a man? To propagate his message, to disseminate the knowledge which is itself the elixir of life. Is this what he does? How could he, if, as he says repeatedly in the dialogues, he does not have that knowledge? [...] Could this be true? If it were, then on his own teaching, he too would be one of the damned. ${ }^{4}$

2. I speculate that Xenophon's view of Socrates would solve the trilemma this way. Evidence for regarding the Xenophontic Socrates as committed to the first two claims in the trilemma can be readily found, but the Xenophontic Socrates appears to be full of the knowledge and wisdom he disclaims having in Plato's texts.

3. Gregory Vlastos, "The Paradox of Socrates," in The Philosophy of Socrates, ed. Gregory Vlastos (Notre Dame, IN: University of Notre Dame Press, 1971), 7. [Repr. from the original version in Queen's Quarterly 64 (1957-58): 496-516].

4. The version of the trilemma I give here is slightly revised from the version originally given in Prior [William J. Prior, "The Portrait of Socrates in Plato's Symposium," Oxford Studies in Ancient Philosophy 31 (2006), 158]. An earlier version was provided in Graham, and the problem itself is certainly discussed in Yonezawa [Daniel W. Graham, "What Socrates Knew," in Wisdom, Ignorance, and Virtue: New Essays in Socratic Studies, ed. Mark. L. McPherran (Edmonton: Academic Printing and Publishing, 1997), 25; Shigeru Yonezawa, "Socratic Knowledge and Socratic Virtue," Ancient Philosophy 15 (1995)]. Yonezawa and Graham argue that Socratic virtue derived from his knowledge of his own ignorance, and they provide several good arguments for why Socrates' awareness of his own ignorance would be a great ethical advantage. Neither explores the relationship between knowledge and craft that I claim solves the problem, so while I am very sympathetic with their arguments, I do not think the answers they give are complete. Their arguments must also confront the objections several scholars make against taking what Socrates says to indicate that he knows that he is ignorant (so see, for examples, Taylor who calls such a view "a clear 
In this paper, I seek to show that we can actually accept each of the above claims. But in order to do so, we must recognize something about each one of the claims that has not received adequate attention in the scholarly literature. Once we attend to what has gone mostly unattended, however, the three claims can be seen as fully consistent.

Although I do not think that attributing any of the three claims in the trilemma is especially controversial, I will begin by offering at least brief reviews of the kinds of evidence we have for each claim - mainly in order to show the cost involved in attempting to get out of the trilemma by simply denying one of the apparently inconsistent claims. I will then introduce the element that renders the entire set of claims consistent, which can thus allow us to understand more precisely the hagiography of Socrates.

\section{Plato's Socratic Hagiography: A (Very) Brief Review of the Evidence}

In the Charmides, for example, where the focus is on temperance ( $\sigma \omega \varphi Q 0 \sigma u ́ v \eta)$, Socrates' responses to the extraordinarily attractive young Charmides provide a vivid example of self-control in the face of strong temptation (Charmides 155b9-156d3). Although perhaps he does not exemplify

misreading of Plato;" see also Fine who also denies that Socrates should be taken to know that he is ignorant) [C. C. W. Taylor, Socrates: A Very Short Introduction (Oxford: Oxford University Press, 1998), 41; Gail Fine, "Does Socrates Claim to Know that He Knows Nothing?," Oxford Studies in Ancient Philosophy 35 (2008)]. Without knowledge of his own ignorance, however, such views cannot account for how (1) and (2) can be consistent. I think Fine speaks for those on both side of this debate when she stipulates that knowledge must be understood as "a truth-entailing cognitive condition that is appropriately cognitively superior to mere true belief" (Fine, "Does Socrates Claim to Know that He Knows Nothing?," 53). In my view, on the contrary, it is the application of this conception of knowledge to the Socratic position that creates the problem. Prior's proposed solution to the problem is somewhat similar to the one for which I argue here, though framed in terms of material from the Symposium. In Prior's view, the Alcibiades of the Symposium wrongly accuses Socrates of being "simply insincere" (Prior, "The Portrait of Socrates in Plato's Symposium," 159) in his disavowals of knowledge. Plato's more balanced portrait reveals a Socrates who has "inner images of virtue" (Prior, "The Portrait of Socrates in Plato's Symposium," 161) that he gained through "at least a second-hand familiarity with the Form of Beauty" (Prior, "The Portrait of Socrates in Plato's Symposium," 152). This "familiarity" would give Socrates something that could look like a share of the knowledge he claims to lack, while also not giving him so much of it that he would be "simply insincere" in disclaiming knowledge. My own view does not call upon cognitive experience of Forms for explaining what I will claim is a degree of knowledge in Socrates. But I see no reason why someone with a more unitarian approach to Plato's dialogues could not make such an application of my argument. 
special courage in the Laches, he is recognized by two of Athens' most famous generals as being a subject worthy of recognition as a potential teacher of that virtue (Laches 180b7-d3). In the Apology, however, Socrates' courage in the face of the threat of death is emphasized repeatedly (see, for examples, 28b3-29d5, 32a5$\mathrm{e} 1,34 \mathrm{~b} 6-\mathrm{e} 2,38 \mathrm{e} 2-39 \mathrm{~b} 1,40 \mathrm{c5}-41 \mathrm{~d} 3$ ), and in the Symposium his resistance to the hardships of hunger and winter cold and in the face of the enemy in war are vividly depicted (Symposium 219e5-221c1). In the Euthyphro, Socrates' younger interlocutor is exposed as a confused fraud, thinking he is an expert about piety; the one revealed as pious in the dialogue is Socrates, who actually manages to get Euthyphro to desist from an impious prosecution of his own father-which Euthyphro's other friends and relatives had thus far failed to get him to do. ${ }^{5}$ So, too, in the Apology, the speech Plato gives to Socrates characterizes the accused man as having gotten into the legal trouble he finds himself in as a result of a mission given to him by the god (23c1, 30a5-7, 30d7-e6, 33c4-7). If so, then it is plainly impious of his prosecutors to seek to rid Athens of Socrates and his divine mission. In that same dialogue, Plato depicts Socrates as a man who always "fights for justice" (31e2-32a3, 32d2-5) and who, at the end of his long life, can say that "I am convinced that I wrong no one" (37b2-3). In the Gorgias, Socrates claims to be the only one alive among his fellow Athenians "to take up the true political craft and practice the true politics" and thus to practice justice in what he does (Gorgias 521d6-8). So when it comes to justice, too, Socrates is depicted by Plato as an exemplar.

But it is not only that Plato depicts Socrates as a model to emulate, Plato also explicitly has Socrates say things about himself that only someone who is virtuous should say. Scholars are well aware of the very close connection that Plato's Socrates makes between virtue and happiness-though there are significant disagreements about precisely how this connection should be interpreted. Some have argued that several ancient schools who conceived of themselves as "Socratic" made the connection one of identity: virtue and happiness are simply the same. ${ }^{6}$ At least one Platonic text seems to come close to saying this explicitly (Crito 48b9), but contemporary scholars have not supported attributing this strong view to Plato's Socrates. Perhaps most scholars, instead, have seen virtue as both necessary and sufficient for happiness in Socratic

5. This reading of the effects of the discussion is controversial: some have claimed that the discussion with Socrates did not have this effect. But the reading I provide here is one I have defended elsewhere [Thomas C. Brickhouse, and Nicholas D. Smith, Routledge Philosophy Guidebook to Plato and the Trial of Socrates (London: Routledge, 2004), 14-18], and is also the one defended long ago by Diogenes Laertius (2.29).

6. See Vlastos [Socrates: Ironist and Moral Philosopher (Cambridge: Cambridge University Press, 1991), 208], who claims this was the view of the Cynics and Stoics. I suspect such an attribution is controversial, however. 
philosophy. ${ }^{7}$ Others claim to find a nomological relationship, instead. ${ }^{8}$ In some earlier work, ${ }^{9}$ I contended that Socrates' claim to be a "good man" (obviously implied by what he says at Apology 41c9-d2) had to be understood in a way that did not entail that he was virtuous, precisely because of his disavowal of the knowledge of virtue (the third claim in the trilemma given above). I now think this was a mistake, and offer what I take to be the appropriate correction to it herein. At any rate, however we take the connection exactly to be between virtue and happiness, it seems to be generally accepted that Socrates would not regard someone who lacked virtue as happy. ${ }^{10}$ Plato, however, characterizes Socrates as an exemplar from this perspective, as well. ${ }^{11}$ In the Apology (36d9-10), Socrates

7. Julia Annas, "Virtue as the Use of Other Goods," in Virtue, Love and Form: Essays in Memory of Gregory Vlastos, ed. Terrence H. Irwin and Martha. C. Nussbaum (Edmonton: Academic Printing and Publishing, 1994); Panos Dimas, "Happiness in the Euthydemus," Phronesis 47 (2002); Terrence H. Irwin, Plato's Moral Theory (Oxford: Clarendon Press, 1977), 100; Irwin, "Socrates the Epicurean?," Illinois Classical Studies 11 (1986): 91; Irwin, Plato's Ethics (New York: Oxford University Press, 1995), 118-120; George Rudebusch, Socrates on Pleasure and Value (New York: Oxford University Press, 1999), ch. 8 and 9; C. D. C. Reeve, Socrates in the Apology (Indianapolis: Hackett Publishing Company, 1989), 136-144; Daniel Russell, Plato on Pleasure and the Good Life (London: Oxford University Press, 2005), ch. 1; Taylor, Socrates: A Very Short Introduction, 64; Vlastos, "The Virtuous and the Happy: Irwin's Plato Moral Theory," Times Literary Supplement 3, no. 961 (1978): 230-231; Vlastos, "Socrates' Contribution to the Greek Sense of Justice," Arkaiognosia 1 (1980): 318-323; Vlastos, Socrates: Ironist and Moral Philosopher, 200-235.

8. Brickhouse, and Smith, Socratic Moral Psychology (Cambridge: Cambridge University Press, 2010), 185-189; Naomi Reshotko, Socratic Virtue: Making the Best of the Neither-Good-Nor-Bad (Cambridge, UK: Cambridge University Press, 2006), ch. 7; Reshotko, "Socratic Eudaimonism," in The Bloomsbury Companion to Socrates, ed. John Bussanich, and Nicholas D. Smith (London: Bloomsbury, 2013), 162-164. In an earlier work, Brickhouse and Smith (Routledge Philosophy Guidebook to Plato and the Trial of Socrates, ch. 4) claimed that virtue was neither necessary nor sufficient for virtue. More recently [Nicholas D. Smith, "Socrates on the Human Condition," Ancient Philosophy 36 (2016)] I have come to accept that Socrates does think that virtue is at least necessary for happiness, but continue to think that the nomological connection described in Brickhouse and Smith (Socratic Moral Psychology) and Reshotko (Socratic Virtue: Making the Best of the Neither-Good-Nor-Bad; "Socratic Eudaimonism") is the correct understand, given the way I have come to understand the necessity thesis.

9. Brickhouse, and Smith, "What Makes Socrates a Good Man?," Journal of the History of Philosophy 28 (1990); Brickhouse, and Smith, Plato's Socrates (Oxford: Oxford University Press, 1994), ch. 4.

10. So I continue to agree with Brickhouse, and Smith [(Plato's Socrates), ch. 4 , see esp. 135] on this point.

11. Vlastos, Socrates: Ironist and Moral Philosopher, 233-5. A dissenting view has recently been argued in Jones [Russell E. Jones, "Felix Socrates?," Philosophia 43 (2013)]. For 
has the audacity to tell his jurors that, unlike an Olympic victor, he does not just make people think they are happy, as he puts it, "I make you be happy!" In the Gorgias he exhorts Callicles to "follow me to where I am, and when you've come here you'll be happy both during life and at its end" (Gorgias 527c4-6). It seems that Socrates is also ready to extend such happiness even into the afterlife: in his third speech in the Apology, Socrates makes it clear that he would regard continuing to do there what he has done in this life as "an extraordinary

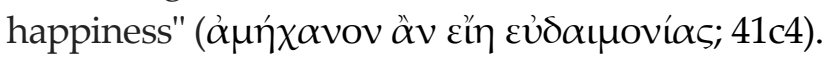

This brief survey of the evidence of Plato's hagiography of Socrates is hardly exhaustive, but is enough, I hope, to show that denying the first of the claims in the trilemma is not a promising way out of our problem. It is tempting to say, indeed, that denying this claim would require a radical departure from most readings of Plato's works, and might now require some very new answer to why it was that Plato decided to feature Socrates as the main speaking character in so many of the dialogues.

\section{Socratic Virtue Intellectualism}

Aristotle's main (and oft-repeated) complaint against Socrates concerned the latter's virtue intellectualism:

Socrates, then, the elder, thought the knowledge of virtue to be the end, and used to inquire what is justice, what bravery and each of the parts of virtue; and his conduct was reasonable, for he thought all the virtues to be kinds of knowledge, so that to know justice and to be just came simultaneously; for the moment we have learned geometry or building we are builders and geometers. Therefore he inquired what excellence is, not how or from what it arises. (Eudemian Ethics A.5.1216b2-10; trans. Solomon) $)^{12}$

The intellectualism about virtue that so bothered Aristotle is also abundantly on display in Plato's dialogues. ${ }^{13}$ At the end of the Protagoras, for example, Socrates despairs at the way his argument with Protagoras has gone:

further debate, see Smith and Jones [Smith, "Socrates on the Human Condition;" Russell E. Jones, "Socrates' Bleak View of the Human Condition," Ancient Philosophy 36 (2016)].

12. Similar Aristotelian criticisms of Socratic virtue intellectualism appear at Nicomachean Ethics Г.8.1116b3-5, Z.13.1144b14-21-30, Eudemian Ethics Г.1.1229a12-16, Г.1.1230a7-10, Magna Moralia A.1.1182a15-23, A.1.1183b8-11, A.20.1190b27-29, and A.34.1198a10-13.

13. This may be one reason why some scholars have claimed that whatever Aristotle thought about Socrates was simply gained from his reading of Plato's dialogues. But there are reasons for thinking that Aristotle was also aware of Xenophon's works, and the same attribution of an intellectualist position to Socrates can also be found 
It seems to me that our discussion has turned on us, and if it had a voice of its own, it would say, mockingly, "Socrates and Protagoras, how ridiculous you are, both of you. Socrates, you said earlier that virtue cannot be taught, but now you are arguing the very opposite and have attempted to show that everything is knowledge-justice, temperance, courage-in which case virtue would appear to be eminently teachable. On the other hand, if virtue is anything other than knowledge, as Protagoras has been trying to say, then it would clearly be unteachable. But if it turns out to be wholly knowledge, as you now urge, Socrates, it would be very surprising indeed if virtue could not be taught." (Protagoras 361a3-b7) ${ }^{14}$

Socratic virtue intellectualism has been a source of great controversy among scholars in recent years. ${ }^{15}$ But their disagreements are mostly on details and not on whether or not Plato depicts Socrates as an intellectualist about virtue. No one seems to doubt this, and on this point it seems ancients and moderns are entirely in agreement. So the second of the three claims that create the trilemma that is our focus here does not seem likely to be mistaken.

\section{The Socratic Disclaimer of Knowledge}

Thus far, I have indicated that there are good reasons for accepting the first two of the claims that create the trilemma for Socratic hagiography. The third-Socrates' profession of ignorance-is both the best attested of the three claims in the works of Plato ${ }^{16}$ but also the claim that scholars have most often called into question (perhaps as a way to avoid the trilemma). ${ }^{17}$

in them. See, for examples, Memorabilia 3.9.5, 4.6.1 and 4.6.11. For further discussion of this topic, see Smith ["Aristotle on Socrates," in Socrates and the Socratic Dialogue ed. Christopher R. Moore, and Alessandro Stavru (Leiden: Brill, forthcoming)].

14. Other texts indicating Socratic virtue intellectualism include Euthydemus 278e3282a7, Meno 89a3-5, Laches 199d4-e4.

15. Brickhouse, and Smith, Socratic Moral Psychology.

16. Examples may be found at Apology 20c1-3, 21d2-7, 23b2-4; Charmides 165b4-c2, 166c7-d6; Euthyphro 5a7-c5, 15c12, 15e5-16a4; Laches 186b8-c5, 186d8-e3, 200e2-5; Lysis 212a4-7, 223b4-8; Hippias Major 286c8-e2, 304d4-e5; Gorgias 509a4-6; Republic I.337e4-5. Other ancient sources also provide support for the attribution of the profession of ignorance to Socrates: see Aristotle, Sophistical Refutations 183b6-8; Aeschines Socraticus Alcibiades 10C (Dittmar); Aelius Aristides Oration 45.21 (W. Dindorff II, p. 25); Antiochus of Ascalon ap. Cicero Academica 1.4.16; Arcesilaus ap. Cicero Academica 1.12.45; Plutarch Against Colotes 117D. The only place in Xenophon where Socrates professes ignorance is limited to the subject of household management (at Oeconomicus I.ii.1213). See note 2 , above.

17. Norman Gully, The Philosophy of Socrates (New York: St. Martin's Press, 1968), 69; L. R. Shero, "Plato's Apology and Xenophon's Apology." Classical World 20 (1927): 
The problem with this way out of the trilemma, however, is obvious-and it is also no doubt why Vlastos himself later repudiated the view he had proposed in his first published work on Socrates: ${ }^{18}$ It would require that Socrates is willing to deceive those to whom he makes his famous disavowals, which would not only include a great number of different interlocutors, but also the jurors at his trial, in spite of his emphatic and repeated claims that he tells them only the truth (Apology 17b5-8, 18a5-6, 20d5-6, 24a4-6, ${ }^{19}$ 28d5, 29e2, 31e1-2, 32a8-9, 33c1-2, 33c9, $34 \mathrm{b5}, 38 \mathrm{a} 7-8,39 \mathrm{~b} 5,41 \mathrm{c} 9)$. It is not surprising, accordingly, that most recent scholarship has taken the Socratic profession of ignorance to be sincere, even if scholars continue to debate its scope and meaning. ${ }^{20}$

\section{A Way Out: $\mu \eta \delta \dot{\varepsilon} v a ̈ \gamma \alpha v$}

My argument in this section is that the problem is actually generated by an incorrect, all-or-nothing understanding of the main claims of the trilemma. To see how this is so, let us first consider the first of the problematic claims: Socrates is an exemplar of virtue. In the very text in which Socrates is singled out as the "wisest of men," it is also quite explicit that his wisdom amounts to nothing in comparison with the wisdom of the god:

What is probable gentlemen, is that in fact the god is wise and that his oracular response meant that human wisdom is worth little or nothing, and that when he says this man, Socrates, he is using my name as an example, as if he said, "This man among you, mortals, is wisest who, like Socrates understands that his wisdom is worthless." (Apology 23a45-b4)

It is a peculiar feature of Socrates' self-assessment that he counts his wisdom as "worthless" in comparison to the wisdom of the god. But does that make him,

109; Vlastos, "The Paradox of Socrates." The most recent and extensively argued expression of such doubts may be found in Senn [Scott J. Senn, "Ignorance or Irony in Plato's Socrates? A Look Beyond Avowals and Disavowals of Knowledge," Plato Journal 13 (2013)].

18. See the quotation from Vlastos at the beginning of this paper. Vlastos explicitly abandons his earlier view in Vlastos ["Socrates' Disavowal of Knowledge," Philosophical Quarterly 35 (1985)].

19. This passage also seems to rule out not just dishonesty, but also any distortion of any kind: "That, gentlemen of the jury, is the truth for you. I have hidden or disguised nothing."

20. An extensive discussion of the recent literature, and an important addition to that literature, may be found in McPartland [Keith McPartland "Socratic Ignorance and Types of Knowledge," in The Bloomsbury Companion to Socrates, ed. John Bussanich, and Nicholas D. Smith (London: Bloomsbury, 2013)]. 
as Vlastos put it, "one of the damned?"21 To answer this question completely correctly, we need to contextualize it. The god, Socrates says, is the one who is really wise, and the wisest of human beings is nothing in comparison. But does that mean that all human beings are equally and utterly worthless when it comes to wisdom? Sub specie aeternitatis, it would seem that we are, but it is also, as we have seen, at the core of Plato's characterization of Socrates that he is even so exemplary among men. From thehuman perspective, Socrates is not only the wisest of men, he is also famously engaged in a mission to persuade us "not to care for your body or your wealth in preference to or as strongly as for the best possible state of your soul" (Apology 30a5-b2). But what's the point? Does Socrates really think that by adjusting our core values and living as he does, we will ever achieve anything more than continuing to be "worthless?" Of course he does! Whatever we might thus achieve will actually still be "worthless" in comparison to the divine. Even so, a man like Socrates is very plainly not "worthless" in comparison to other human beings. From the god's-eye view, even the loftiest of human achievements, when it comes to wisdom, are nothing. Plato does not want us to forget that fact; but he also wants us to recognize that there is another perspective available to us - a human perspective-and from this vantage point, there can be very significant differences between people, for better and for worse.

At the heart of scholars' puzzlements about Socrates' profession of ignorance is a conception of the knowledge that Socrates claims not to have that is so familiar to us from contemporary philosophical analyses as to be the starting point for scholarly interpretation. In this conception, knowledge is a cognitive state of a certain kind - what is called a "threshold" achievement, like being pregnant or tall enough to ride on the rollercoaster at the local amusement park. Either one has achieved the cognitive condition of knowledge with respect to some specific bit of information or one has not, and it all depends on what we take the necessary conditions of knowledge to be, and whether some cognitive agent has met those conditions in some instance, or not. If we apply this conception of knowledge to Socrates, then when he claims not to have knowledge, he should be taken as saying that he has not met the conditions necessary to be in a cognitive state of knowledge about some subject under discussion.

Even if we take this to be the correct way to understand Socrates' profession of ignorance, it is worth noticing that Socrates could nonetheless think there were very significant differences among those who failed to have knowledge, depending on the extent and degree to which they failed to meet the necessary conditions of knowledge. For example, we might broadly

21. Vlastos, "The Paradox of Socrates," 7. 
conceive of knowledge as warranted (or justified) true belief. ${ }^{22}$ Plainly, two people might share the same true belief on some subject, and both might fall short of knowledge, but one might have far more or better warrant (or justification) for the belief than the other. So even if we assume that Socrates conceived of knowledge as a threshold achievement, he could still hold that some human beings were a great deal further along in approximating that achievement than others, even if all of us actually ended up falling short. In this way of thinking, Socrates' being the "wisest of men" would amount to his having much better justification or warrant for his beliefs, even if neither he nor anyone else actually knew anything important. ${ }^{23}$

The problem with this way of explaining how Socrates is better than other human beings comes when we try to apply it to the second of the claims in the trilemma: Virtue is a kind of knowledge. The problem is that even if we can credit Socrates as being much superior to other human beings in ways that do not amount to knowledge, these will avail him nothing when it comes to virtue. If virtue is a kind of knowledge, but knowledge is a threshold achievement and Socrates has not reached that threshold, then he has also not achieved virtue. It might still be true that Socrates could approximate virtue to the same degree as he approximates knowledge in his better warranted or better justified beliefs. But if knowledge is a threshold he has not reached, then it is still the case that Socrates cannot be wise, cannot be just, or moderate, pious, or courageous. ${ }^{24}$ If so, it makes no sense to characterize him as an exemplar of any of these virtues, since as a matter of fact he has achieved none of them.

Here, then, is the very heart of the problem. It is a problem, I contend, scholars themselves have created by applying an anachronistic conception of knowledge to our texts. If we go back and look at the very text in which

22. For a discussion about why we might prefer one of these two formulations, see Evans and Smith [Ian Evans, and Nicholas D. Smith, Knowledge (London: Polity Press, 2012), chapters 1, 4, 6].

23. Scholarship on Socratic ignorance has struggled with the fact that Socrates both disclaims having knowledge, but also occasionally claims to have knowledge. See McPartland ["Socratic Ignorance and Types of Knowledge"] for a full review of these discussions. I now think the debates about this subject are mostly beside the point, since I think that the sense of knowledge engaged in such debates conceives it as a threshold achievement. In any case, no one seems to disagree that Socrates disclaims having the kind of knowledge that amounts to wisdom about "the most important things" (see Apology 22d7). Compare Euthydemus 293b7-8.

24. I base this claim on Socrates' apparent endorsement of what has come to be known as the "unity of virtue" or "the unity of the virtues," for which, as with so many other Socratic views, there has been a number of interpretations given. But this result would follow for any of the interpretations of the relevant unity that I am aware of. (For discussion of the interpretive alternatives, see Brickhouse and Smith (Socratic Moral Psychology, section 6.2.) 
Socrates explains the origins of his reputation for wisdom, we find a very different conception of knowledge in play. After hearing about the Delphic oracle to Chaerephon about his supposed wisdom and wondering at it, Socrates seeks to understand the meaning of the oracle ${ }^{25}$ by going to people reputed to be wise. He finds that politicians think they know something worthwhile, but actually do not (21d2-22a8). Poets, too, turn out to know nothing of significance, but suppose themselves to be very wise (22a8-c8). He then turns his attention to the craftspeople.

Finally I went to the craftsmen, for I was conscious of knowing practically nothing, and I knew that I would find that they had knowledge of many fine things. In this I was not mistaken; they knew things I did not know, and to that extent they were wiser than I. But, gentlemen of the jury, the good craftsmen seemed to have the same fault as the poets: each of them, because of his success at his craft, thought himself very wise in other most important things, ${ }^{26}$ and this error of theirs overshadowed the wisdom they had, so that I asked myself, on behalf of the oracle, whether I should prefer to be as I am, with neither their wisdom nor their ignorance, or to have both. The answer I gave myself and the oracle was that it was to my advantage to be as I am. (Apology 22c9-e6)

There are several things to notice here:

1. As Socrates puts it at the end of this description, he finds that he actually is at an "advantage" relative to those he examined. In other words, the oracle turned out to be literally correct: none of those he examined turned out to be wiser than he is. Instead, he is wiser than they are. The way Socrates conceives of things does not simply make him less deficient than others, but actually advantaged. His point is not about a reduction of a deficit, but about his having achieved a positive condition, relative to theirs. ${ }^{27}$ Moreover, Socrates also endorses what has come to be known as

25. Not "refute" the oracle, as many have proposed, along with an insinuation that this somehow indicates a certain degree of skepticism about customary religious

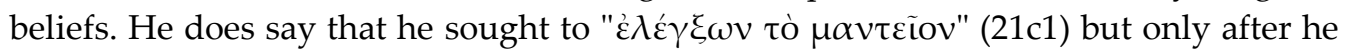

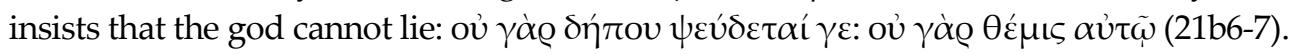

26. Translation modified here. The text does not include anything so specific as "pursuits," as the Grube translation in Cooper (Plato: Complete Works) has it. Rather, the Greek supplies only a neuter plural ( $\tau \tilde{\alpha} \lambda \lambda \alpha \tau \dot{\alpha} \mu \dot{\varepsilon} \gamma(\sigma \tau \alpha-22 \mathrm{~d} 7)$, which is probably best rendered in the way I have here. On the other hand, as my subsequent argument will show, I do not disagree with Grube that these "most important things" should not be supposed to be the contents of something like justified true beliefs, but rather concern activity and practical application.

27. For a discussion of the significance of these different ways of describing the Socratic advantage, see Smith 2016 vs. Jones 2016 [Smith, "Socrates on the Human Condition," vs. Jones, "Socrates' Bleak View of the Human Condition"]. As I understand 
the "unity of virtue." The specific ways in which we are to understand this view - that all of the virtues are in some sense the same-has been a matter of debate among scholars. ${ }^{28}$ But taken in any of the ways that scholars have proposed, it would follow that insofar as Socrates is not wise, neither is he pious, just, temperate, or courageous. Insofar as he is wise, however, he is also all of the rest of these. It follows that we must understand Socrates' claim to be wiser than others-even if, again, only to a degree that is beneath notice from the divine point of view-as conclusive evidence that he is also more pious, just, temperate, and courageous. Accordingly, his claim of advantage in this text amounts to an explicit admission and explanation of what I am calling Plato's Socratic hagiography.

2. Unlike the politicians and poets, Socrates finds that the craftsmen actually do know some things and this knowledge does constitute wisdom that they have. No doubt the craftsmen have cognitive states that we would call knowledge and that Socrates does not have, because he has not learned what the craftsmen have learned, in learning their crafts. But Socrates is not talking about facts that they are justified in believing; instead, the craftsmen have their crafts, certain skills, abilities, or capacities to do those things associated with that craft. It is their know-how, in other words (and not some kind of knowing that) that Socrates compares to his own lack, and which gives the craftsmen an advantage over Socrates to that extent. But their knowledge (-how) and wisdom is not the kind that Socrates cares so much about-wisdom in what he here calls "other most important things"-and moreover the craftsmen seem to think they have that other wisdom when they do not have it. Because Socrates is aware that he does not have this other wisdom, he does not make the error made by the craftsmen. His not making this error more than makes up for the other advantages the craftsmen have, which is constituted by the wisdom that they have.

the view provided in Jones, Socrates' superiority to other human beings should be understood in terms of his having achieved a closer approximation to virtue than others, while still falling short of virtue in any positive sense. Both Jones and Smith endorse the idea that virtue may come in degrees. Their dispute is on whether Socrates would think he has achieved at least some degree of virtue, or continues to fall short of such an achievement.

28. See, for examples of different approaches, Vlastos, "The Unity of the Virtues in the Protagoras," in Platonic Studies (2nd Edn.), ed. Gregory Vlastos (Princeton: Princeton University Press, 1981); Terry Penner "The Unity of the Virtues," Philosophical Review 82 (1973); Penner, "What Laches and Nicias Miss-and Whether Socrates Thinks Courage is Merely a Part of Virtue," Ancient Philosophy 12 (1992); Brickhouse, and Smith, "Socrates on the Unity of the Virtues," Journal of Ethics 1 (1997); Brickhouse, and Smith, Socratic Moral Psychology, 154-167. 
This focus on craft-knowledge, or what we often call "know-how," has come to be known as Socrates' "craft analogy." The "analogy"29 is one that Socrates invariably makes between having some (other) craft and having virtue-between being a carpenter, for example, and being pious, or just, or courageous. The "analogy" is the result of Socrates being an intellectualist about virtue - that is, again, his view that virtue is a kind of knowledge. But it is a kind of knowledge that we should not confuse with fact-knowledge-with the threshold cognitive state that we typically have in mind when we do contemporary theory of knowledge. It is, rather, skill or know-how. ${ }^{30}$

One very important consequence may immediately be drawn from this point: know-how is not an all-or-nothing affair, but rather a matter of degree and one can become better at a certain kind of skill. For example, having attended dancing school when I was an adolescent, I know how to dance the cha-cha. Having not practiced at dancing the cha-cha for many years now, I think it is most accurate to say that my knowledge of the cha-cha amounts to being able, rather clumsily, to do the basic step. For a professional ballroom dancer, my own skill would be so poor as probably not even to qualify as dancing the cha-cha (or perhaps not even as dancing at all). So the standards by which we measure some skill-for example, someone's knowing how to dance the cha-cha-are going to be highly contextual. At a professional ballroom dance competition, I would be immediately disqualified as hopelessly inept. Compared to someone who never learned the basic steps of the cha-cha, however, I qualify as (maybe even still just

29. I put the word in "scare" quotes because in my own view the Socratic "craft analogy" is not an "analogy" at all; it is, rather, a conviction. Virtue, for Socrates, is not merely like a craft; virtue is a craft-the ultimate craft.

30. I have claimed that this fact has gone mostly unnoticed by scholars, but there are indications in Senn that he sees at least some gradability in Socrates' views. See esp. Senn: "Socrates clearly he thinks he has a goodness (or at least some degree of it relative to whatothers have or do not have)" (Senn, "Ignorance or Irony in Plato's Socrates?, 87). But Senn immediately seems to ignore the consequence of the relativity of Socrates' claim when he continues by claiming that Socrates' relative goodness "affords hima remarkable kind of protection against anyinjury (including injury from death, exile, disenfranchisement, as well-one assumes-as from imprisonment, torture, maiming) that an inferior may try to bring about for him." Had Senn also recognized the gradability in this consequence of Socrates' goodness, it seems we would be in agreement. I do agree with Senn when he claims that "all that ultimately matters to Socrates-as far as goodand bad, benefit and harm is concerned-is something that he thinks he has already got (at least some of)" (Senn, "Ignorance or Irony in Plato's Socrates?, 87). We differ on just how much this "at least some of" counts, for Socrates. Senn concludes that the profession of ignorance is insincere. In my view, it is sincere because Socrates continues to regard himself as falling far short of his aspiration standards when it comes to knowledge. Elsewhere, Senn argues against the idea that Socrates thinks virtue is a craft, skill, or expertise [Senn, "Virtue as the Sole Intrinsic Good in Plato's Early Dialogues," Oxford Studies in Ancient Philosophy 28 (2005)]. 
barely) knowing how to do the dance. But this is a very important difference from the cognitive state we tend to have in mind when someone talks about knowledge. Knowing how is not a threshold achievement, it is, rather, one that is gradable. ${ }^{31}$

This is not to say, however, that knowledge-that or fact-knowledge has nothing to do with the sort of knowledge that Socrates has in mind as a virtue intellectualist. To return to my example of knowing how to dance the cha-cha, it seems that one must at least know that the basic step is a one-two, one-two-three. A carpenter must know that this tool is a hammer and that one is a saw, and also know that the saw is used to cut wood, and so on. We should also remind ourselves that the Socrates we see at work in Plato's dialogues seeks definitional knowledge, and seems to think that those who actually have some virtue will be able to define it-and definitions, plainly, are propositional in form. But this entails only that Socrates conceives of the know-how that constitutes virtue as necessarily including knowing how to define virtue. We might plausibly suppose that this sort of know-how, too, will come in degrees, and thus also infer that Socrates must suppose that he can do a better job of this than can any of the interlocutors with whom he speaks in the dialogues. ${ }^{32}$ So in saying that Socrates' virtue intellectualism has a kind of know-how as the sort of knowledge in which virtue consists, we should not suppose that there is nothing in our texts that rules out uses of epistemic terms that would be readily suited to the more familiar versions of contemporary epistemology. The distinction made herein is about which sort of knowledge is the essence of Socratic virtue intellectualism. Knowledge that may be symptomatic of knowing how, or even a necessary condition of it. Accordingly, we should not be surprised when Socrates seems to

31. Such gradability does not mean that even the smallest share of know-how will count as an example of the relevant skill-again, what will count as at least enough to qualify as an example of real skill (even if incomplete or only partial) will generally be a matter of context and the standards applicable to that context.

32. One account of how Socrates helps others to improve their skill in giving definitions may be found in May 1997. My claim here presupposes that Socrates thinks that some attempts to give a definition of a given virtue are better than others. A complete argument for this claim would require much more than I can provide here, but I would ask skeptical readers to review the many different ways in which Socrates responds to definitions that his interlocutors offer. For example, to those who offer mere lists of examples, Socrates' responses are simply dismissive. Usually by the end of a definitional dialogue (the Euthyphro is a particularly good example), it seems that some progress towards an adequate definition has been made-even though there are no cases in which a fully adequate definition is ever reached. As such, it is also clear from what I am claiming that I am inclined to regard Socratic argumentation as not simply refutative, not intended simply to expose ignorance. I understand that this view is controversial, but again, it is a controversy I cannot engage adequately herein. 
indicate that no one could be good or virtuous who fails to know (that) something or other is true. ${ }^{33}$

Now, the gradability of the knowledge Socrates has in mind when he talks about wisdom should have been obvious all along from the whole point Socrates is making when he compares himself to the politicians, poets, and craftsmen - his point, after all, is that he actually is wiser than others. If he had a threshold achievement in mind, such a comparative would be inapt: no one is more tallenough-to-ride-the-roller-coasterthan anyone else who has cleared that threshold-even if it remains true that some who have cleared that threshold are indeed taller than others. No one, similarly, is more pregnant than anyone else who is pregnant. One pregnant person may be further along in the pregnancy-or might perhaps be pregnant with twins instead of a single fetus; but neither of these would make that person more pregnant than some other pregnant person. But the comparative, for Socrates, is the whole point.

If we try to take this point further, however, we encounter an interesting puzzle. Let us grant (what I hope has now been established) that Socrates intends to be comparing degrees of some gradable skill(s). He compares his own level of skill with what he finds in the craftsmen, and decided that he is more skilled than they. Now, what they are more skilled at is obvious: they are more skilled at their crafts than Socrates is skilled at those crafts. But in what is Socrates more skilled? It seems he is more skilled in the only other kind of wisdom that is mentioned in the passage, and only just mentioned: skill in "other most important things." He does not say what these other things are, or why they are "most important." But whatever they are, it is clear that Socrates not only thinks they are more important than whatever skills the craftsmen actually do have, and also that the jury will at least understand that there are more important things that one might aspire to be wise about than the practices and products of the (other) crafts. But even so, we might pause to wonder what Socrates has in mind-and what he expects his jurors to have in mind-when he declares that what he has amounts to being wiser than what the craftsmen have, despite their obvious advantages.

The complaint against Socrates is that he has a reputation for wisdom, and it is this reputation that he seeks to explain in this passage (see Apology 20d6-7). If wisdom is to be understood as a kind of know-how or skill, then what Socrates is explaining to the jurors is how and why he (rightly) has come to have a reputation for having more of this know-how or skill than others-indeed, if the oracle is right, there is no one who has it more than Socrates. But even though he has this reputation, and even though Socrates is convinced that he really is more skilled than others, the actual nature and content of that superior skill is not here

33. One example among many might be where Socrates says that he "knows that it is evil and disgraceful to do what's wrong and to disobey one's superior, whether god or man" at Apology 29b6-7. Such knowledge, we may suppose-or at least the relevant belief-would be required for anyone even to approximate virtue. 
specified. So what is it? I propose that the superior skill that Socrates has a reputation for having is what he and the jurors would count as real wisdom - the same kind(s) of skill he and they would count as real virtue, $\alpha$ ¿ern. ${ }^{34}$ The cratsmen have the virtue of their crafts, which is to say that they can be goodor even excellentat what they do. Socrates is not good at what the craftsmen are good at. Instead he is good in the way that really matters. That is what he has come to have a reputation for, and he is telling his jurors here that his reputation is actually correct, at least relative to other human beings. He is better than other human beings. Later on, he reassures the jurors who voted for him that the gods do not neglect good men (41d1). The point is obvious: he has not been harmed by what has happened, despite the result of the trial, because he is a good man and the gods look out for good men. So again, the entire effect of this passage is an emphatic endorsement of what I am herein calling Plato's hagiography of Socrates.

The way in which Socrates is so much better than other men is not an all-ornothing matter, but a matter of skill and conduct. It is not that he has some specific cognitive state-some justified true belief(s) that others do not have-nor is his condition a threshold achievement. As something more like a skill-the most valuable of all skills-whatever Socrates has is something we can all improve in, and it is this message that he brings to the Athenians as if he were a "gift from the god" (Apology 30d8). We should care more about attaining this skill (29d7-30b4, 31b4-5, 38a1-7). Because this is what he has dedicated his life to doing, Socrates actually claims to make people happy (36d10). Scholars have been struck by what amounts to the same claim in another dialogue, where he boldly says that he is the only one among his contemporaries to have taken up the "true craft and practice of politics" (Gorgias 521d6-8). Because craft knowledge is gradable, this need not be taken as a claim of any sort of mastery. Perhaps we should suppose instead that Socrates would count himself as only the most novice of apprentices at this craft. Relative to the god, of course, whatever achievement he has made is beneath notice. But relative to other mere human beings, he is an exemplar. That, I take it, is the main point of Plato's portrait of Socrates.

34. Given the way Fine understands the knowledge that is constitutive of wisdom (see note 4, above), she concludes that the only "wisdom" Socrates has is "not genuine wisdom" (Fine, "Does Socrates Claim to Know that He Knows Nothing?," 79). As I have been arguing, this leaves Socrates with no real advantage in wisdom over the

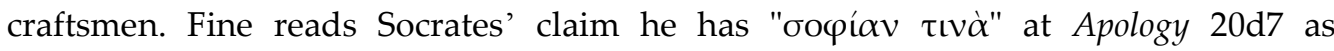
meaning not that he has a kind of wisdom, but rather that what he has is "something like wisdom" (Fine, "Does Socrates Claim to Know that He Knows Nothing?," 79). Thus, in her view, "Socrates distinguishes wisdom from something that is like wisdom, but is not wisdom at all" (Fine, "Does Socrates Claim to Know that He Knows Nothing?," 80). This, however, seems to destroy the very claim that Socrates is seeking to make here, which is that Socrates is superior in wisdom to the craftsmen, in spite of the real wisdom they have in their crafts. 
The god, or a true master craftsman of virtue (and I am inclined to think that only the former could be the latter), would always make the best choices in any given circumstance. At the other extreme, an ignoramus would only ever make anything like a good choice by accident. I do not think that any of the even very striking claims that Socrates sometimes makes about his own achievements amount to claims about having always or even perhaps ever making the best choices he might have made, or about having achieved the best results he might have achieved with a higher degree of wisdom. But the reliable production of better results, relative to the efforts of those who think they have wisdom they do not have, or even relative to those who-like Socrates-acknowledge that they lack wisdom, but are also not yet as far along in living examined lives, is something I claim indicates a level of ability, with respect to virtue, that would earn Socrates the obvious reverence we find in the Platonic portrait. Socrates can thus rightly and candidly claim to be a good man. But his very real goodness still falls short of anything like perfection. Thus, disclaimer of wisdom is sincere and also accurate, as are the many cases in which he disclaims having knowledge of the topic he discusses with his interlocutors, since that disclaimer is a disclaimer of the kind of knowledge that would be had by the true expert-which Socrates is not.

\section{Two Alternatives Considered}

In the last section I argued that the kind of knowledge that Socrates thought virtue consisted in is gradable. But we would do well now to acknowledge that accepting this does not all by itself get us out of the trilemma. As I indicated (perhaps too briefly) at the beginning of that section, those who do not understand knowledge as gradable, for Socrates, might argue that although knowledge is not gradable, one's level of justification or warrant for a true belief could well be gradable. Accordingly, as I put it there, one might argue that Socrates took knowledge to be something that neither he nor any other mere human being had achieved, but still compare himself cognitively (and this ethically, given his intellectualism) favorably to others. Following the way I characterized this view early in the last section, let us call this the "approximation view" or AV, for short. It would be a variant of this view that Socrates took "wisdom" only to refer to the perfection of virtue had by a god, and thus all human beings to fall short of that achievement. But even so, it could well be that Socrates (and anyone else who made a genuine attempt to lead "the examined life") could be counted as approximating this aspirational ideal more than others.

In AV, we should understand Socrates' own cognitive and ethical selfassessment as being that he has achieved a better approximation of virtue than the politicians, poets, and craftspeople. So could this (AV) perhaps be 
what Plato's hagiography of Socrates amounts to? I think not. If we go on to try to make our way out of the trilemma in $\mathrm{AV}$, we encounter problems. The first of these might make its appearance when we try to adjust the second point of the trilemma in such a way as to allow Plato to make his case for Socrates. The problem is that Socrates plainly says that virtue is a kind of knowledge and (given the unity of virtue) all virtue to be none other than wisdom. Now, suppose we attempt to understand the way that Socrates exhorts us to improve ourselves in the way that AV requires. For example, consider the way he puts this in the Euthydemus:

[Socrates speaking] Then let us consider what follows: since we all wish to be happy, and since we appear to become so by using things and using them rightly, and since knowledge was the source of rightness and good fortune, it seems to be necessary that every man should prepare himself by every means to become as wise as possible. (Euthydemus 282a1-6)

Taking "wise" here to mean the kind of infallible cognitive perfection of a god, we will see Socrates as urging us to "become as infallible as possible." The problem - and at the heart of AV - is that the kind of knowledge/wisdom that is the only one we should recognize is not one that allows of degrees. If Socrates makes only three errors in roughly twenty attempts per day at some task, whereas I make fifteen errors in the same number of attempts per day, that does make Socrates less fallible than I am in that task, but it does not make him "more infallible." So similarly, if all fall short of knowledge or wisdom, then some (e.g. Socrates) may qualify as less ignorant than others, but none will qualify as more knowing or more wise, since none will actually achieve these ideals. So if this were Socrates' view of things, it would not make sense for him to exhort us "to become as wise as possible," since becoming wise at all would not be an option for any of us. Moreover, it would not make sense for Socrates to claim to be wiser than anyone else (much less "the wisest," since he would not be wise at all. But plainly this does not match what Socrates actually says about himself. Accordingly, I claim that my own view - that Socrates actually has achieved a level of what really does count as knowledge and wisdom (even if he still regards it as a very low grade of each) - fits what Socrates actually says on this topic than AV does.

Another view of the matter has recently been argued by Russell Jones. ${ }^{35}$ Jones allows that, for Socrates, knowledge (-how) and this wisdom and virtue are at least in principle gradable. ${ }^{36}$ But Jones also understands Socrates as assessing his own achievement as being below the level he would have needed to reach to have enough of what he says he lacks to qualify as

35. Jones, "Felix Socrates?;" Jones, "Socrates' Bleak View of the Human Condition."

36. Jones, "Socrates' Bleak View of the Human Condition, 99-100. 
knowing or as wise. He asks us to compare what Socrates seems to have in mind when he discusses virtue with the level of interconnected skills we would require of someone before we would agree to identify them as having the craft of house-building. Jones's point is that one would have to be very nearly a master of all of the relevant skills for us to count the person as having the craft of house-building. ${ }^{37} \mathrm{He}$ then completes his comparison: ${ }^{38}$

It is not a trivial move from supposing that wisdom and happiness are gradable and that greater wisdom will tend to greater happiness to the claim that some minimal happiness is fairly-achievable. To make that move, we would first have to determine what minimal standards a life must meet to be happy at all; and then to determine what degree of wisdom is required to reach such standards.

Jones contends that Socrates sets these standards high enough that he counts himself as not having met them. Accordingly, with respect to the trilemma that is my focus herein, Jones concludes that even if we grant that knowledge(-how), wisdom, virtue, and happiness are all gradable, as I have claimed, it is simply wrong to see Socrates as an exemplar of virtue (per the first statement of the trilemma). So it would follow from Jones's view that if there is a "hagiography of Socrates" in the works of Plato, as I claim there is, it cannot be conceived in such a way as to include the first item in the trilemma.

Jones has not expressed a view about in what way Plato might have taken Socrates to be an exemplar. It is possible that Jones would prefer AV to the account that I have given, since AV, too, rejects the first item in the trilemma. But however he might reconceive the items in the trilemma to accommodate his claims about Socrates views of his own inadequacies (in knowledge, wisdom, virtue, and happiness), I have also claimed (herein, and in my debate with him ${ }^{39}$ ), that several things Socrates says about himself and others do not sustain Jones's account of "Socrates' bleak view of the human condition." As I noted in the section entitled, "Plato's Socratic Hagiography: A (Very) Brief Review of the Evidence," Plato has Socrates make several claims (Apology 36d9-10, 41c4, and Gorgias 527c4-6) about his own and others' (possible or actual) achievements of happiness that, given the necessity of virtue for happiness, can only be rendered consistent with the rest of Socratic philosophy if he accepts that he actually has achieved a sufficient level of knowledge/wisdom/virtue to permit him to be positively happy, rather than simply less wretched than others. And the hortative aspect of Socrates' "mission" is such as to promise those of us who will join him in seeking "to become as wise as possible" a chance to achieve at least that same level of happiness, to the degree that we succeed in our quest for

37. Ibid., 100.

38. Ibid.

39. Smith, "Socrates on the Human Condition." 
virtue. So while I agree with Jones's point that not just any grade of knowledge or wisdom will be enough, I continue to think that Socrates counts himself as positively wise (and not merely less deficient-less ignorant) than others, and also to that degree as positively happy (and not merely less deficient-less wretched) than others.

\section{Summary and Conclusion}

I began with what I characterized as a trilemma facing Plato's hagiography of Socrates-the result of a characterization of Socrates as an exemplar of virtue, as a virtue intellectualist, and as someone who disclaimed knowledge and wisdom. I have focused on one particular expression of the Socratic profession of ignorance in Plato's Apology to show that it was never intended to amount to making Socrates "one of the damned," as Vlastos so colorfully put it. ${ }^{40}$ The way out of the trilemma, I have claimed, comes from recognizing the gradability of the kind of knowledge and wisdom that Socrates exemplifies, the kind of knowledge and wisdom that virtue consists in, and thus the degree to which Socrates and others can be ignorant. Socrates qualifies as the wisest and the most virtuous of human beings, because in comparison with others, he works the hardest (and is at least to some degree reliably effective in his efforts) to improve in the most important of skills. Relative to a god, of course, he is "worthless," and relative to his own aspirational ideals, he is painfully aware that he has a long way to go. Even so, if we compare him to other (mere) human beings, he is an exemplar-and his modest disclaimers never amount to a denial of that fact. Indeed, as we can see, although he is careful to remind us that one's proper aspirational goals should always aim much higher than he has achieved himself, Socrates actually affirms his exemplary status, and also says that we would do well to emulate him. He is ignorant, and offers little hope for any of us to be less ignorant than he is. But such ignorance is a matter of our humanity, and is also a matter of degree. We would all do well to be like Socrates, always trying our best to remediate our human condition of ignorance. We may thus become happy - at least, as happy as a human being can be. In so doing, we may also become "god-like" (see Theaetetus 176a5-c3):41 not as gods, but as like them as human beings can ever be.

40. Vlastos, "The Paradox of Socrates," 7.

41. For discussion of this theme in Plato, see Sedley [David Sedley, "The Ideal of Godlikeness," in Plato 2: Ethics, Politics, Religion, and the Soul, ed. Gail Fine (Oxford: Oxford Readings in Philosophy, 1999); and more recently Giannopoulou (Zina Giannopoulou, "Socrates and Godlikeness in Plato's Theaetetus," Journal of Philosophical Research 36 (2011)]. 


\section{Acknowledgements}

I have benefited from comments on earlier drafts of this paper by Emily Austin, Michelle Jenkins, Russell Jones, William Prior, Chiara T. Ricciardone, Scott Senn, and Ravi Sharma-none of whom should be presumed to agree with my arguments or conclusions herein. All remaining errors are mine alone.

\section{Bibliography}

Annas, Julia. "Virtue as the Use of Other Good." In Virtue, Love and Form: Essays in Memory of Gregory Vlastos, edited by Terrence H. Irwin, and Martha. C. Nussbaum, 53-66. Edmonton: Academic Printing and Publishing, 1994.

Brickhouse, Thomas C., and Smith, Nicholas D. Socratic Moral Psychology. Cambridge: Cambridge University Press, 2010.

_. Routledge Philosophy Guidebook to Plato and the Trial of Socrates. London: Routledge, 2004. . "Socrates on the Unity of the Virtues." Journal of Ethics 1 (1997): 311-324. . Plato's Socrates. Oxford: Oxford University Press, 1994. . "What Makes Socrates a Good Man?." Journal of the History of Philosophy 28 (1990): 169-179.

Cooper, John M. ed. Plato: Complete Works. Indianapolis: Hackett Publishing Company, 1997.

Dimas, Panos. "Happiness in the Euthydemus." Phronesis 47 (2002): 1-27.

Evans, Ian, and Smith, Nicholas D. Knowledge. London: Polity Press, 2012.

Fine, Gail. "Does Socrates Claim to Know that He Knows Nothing?." Oxford Studies in Ancient Philosophy 35 (2008): 49-88.

Giannopoulou, Zina. "Socrates and Godlikeness in Plato's Theaetetus." Journal of Philosophical Research 36 (2011): 135-148.

Graham, Daniel W. "What Socrates Knew." In Wisdom, Ignorance, and Virtue: New Essays in Socratic Studies, edited by Mark. L. McPherran. Edmonton: Academic Printing and Publishing, 1997.

Gully, Norman. The Philosophy of Socrates. New York: St. Martin's Press, 1968.

Irwin, Terrence H. Plato's Ethics. New York: Oxford University Press, 1995. . "Socrates the Epicurean?." Illinois Classical Studies 11 (1986): 85-112. . Plato's Moral Theory. Oxford: Clarendon Press, 1977.

Jones, Russell E. "Socrates' Bleak View of the Human Condition." Ancient Philosophy 36 (2016): 97-105. "Felix Socrates?." Philosophia 43 (2013): 77-98. 
McPartland, Keith. "Socratic Ignorance and Types of Knowledge." In The Bloomsbury Companion to Socrates, edited by John Bussanich, and Nicholas D. Smith. London: Bloomsbury, 2013.

Penner, Terry. "What Laches and Nicias Miss-and Whether Socrates Thinks Courage is Merely a Part of Virtue." Ancient Philosophy 12 (1992): 1-27.

__. "The Unity of the Virtues." Philosophical Review 82 (1973): 35-68.

Prior, William J. "The Portrait of Socrates in Plato's Symposium." Oxford Studies in Ancient Philosophy 31 (2006): 137-166.

Reeve, C. D. C. Socrates in the Apology. Indianapolis: Hackett Publishing Company, 1989.

Reshotko, Naomi. "Socratic Eudaimonism." In The Bloomsbury Companion to Socrates, edited by John Bussanich, and Nicholas D. Smith, 156-184. London: Bloomsbury, 2013.

__. Socratic Virtue: Making the Best of the Neither-Good-Nor-Bad. Cambridge, UK: Cambridge University Press, 2006.

Rudebusch, George. Socrates on Pleasure and Value. New York: Oxford University Press, 1999.

Russell, Daniel. Plato on Pleasure and the Good Life. London: Oxford University Press, 2005.

Sedley, David. "The Ideal of Godlikeness." In Plato 2: Ethics, Politics, Religion, and the Soul, edited by Gail Fine, 309-328. Oxford: Oxford Readings in Philosophy, 1999.

Senn, Scott J. "Ignorance or Irony in Plato's Socrates? A Look Beyond Avowals and Disavowals of Knowledge." Plato Journal 13 (2013): 77-108.

__. "Virtue as the Sole Intrinsic Good in Plato's Early Dialogues." Oxford Studies in Ancient Philosophy 28 (2005): 1-21.

Shero, L. R. "Plato's Apology and Xenophon's Apology." Classical World 20 (1927): 107-111.

Smith, Nicholas D. "Aristotle on Socrates." In Socrates and the Socratic Dialogue edited by Christopher R. Moore, and Alessandro Stavru. Leiden: Brill, forthcoming. . "Socrates on the Human Condition." Ancient Philosophy 36 (2016): 81-95.

Taylor, C. C. W. Socrates: A Very Short Introduction. Oxford: Oxford University Press, 1998.

Vlastos, Gregory. Socrates: Ironist and Moral Philosopher. Cambridge: Cambridge University Press, 1991.

_. "Socrates' Disavowal of Knowledge." Philosophical Quarterly 35 (1985): 1-31.

_.. "The Unity of the Virtues in the Protagoras." In Platonic Studies (2nd Edn.), edited by Gregory Vlastos. Princeton: Princeton University Press, 1981.

_. "Socrates' Contribution to the Greek Sense of Justice." Arkaiognosia 1 (1980): 310-324.

. "The Virtuous and the Happy: Irwin's Plato Moral Theory," Times Literary Supplement 3, no. 961 (1978): 230-231. 
__. "The Paradox of Socrates." In The Philosophy of Socrates, edited by Gregory Vlastos. Notre Dame, IN: University of Notre Dame Press, 1971. [Repr. from the original version in Queen's Quarterly 64 (1957-58): 496-516].

Yonezawa, Shigeru. "Socratic Knowledge and Socratic Virtue." Ancient Philosophy 15 (1995): 349-358. 
